\title{
PUBLIC PARTICIPATION IN ENVIRONMENTAL IMPACT ASSESSMENT AND ITS SUBSTANTIVE CONTRIBUTION TO ENVIRONMENTAL RISK MANAGEMENT: INSIGHTS FROM EIA PRACTITIONERS AND OTHER STAKEHOLDERS IN KENYA'S RENEWABLE ENERGY SUB-SECTOR
}

\author{
PHILIP M. OMENGE ${ }^{1}$, GEORGE W. ESHIAMWATA ${ }^{2}$, \\ STANLEY M. MAKINDI ${ }^{3}$ \& GILBERT O. OBWOYERE ${ }^{1}$ \\ ${ }^{1}$ Egerton University, Kenya \\ ${ }^{2}$ The Kenya National Commission for UNESCO, Kenya \\ ${ }^{3}$ Machakos University, Kenya
}

\begin{abstract}
Comprehensive and transparent public participation during Environmental Impact Assessment (EIA) processes for renewable energy projects is vital in identifying, addressing and mitigating potential environmental risks associated with such renewable energy projects. Public participation during EIA is a vital platform where all stakeholders of a given renewable energy project contribute to addressing the environmental concerns of renewable energy projects, thereby contributing positively to informed environmental decisions that mitigate negative environmental impacts. This paper presents a comparative analysis of public participation practice during an EIA process in Kenya's renewable energy sub-sector vis-à-vis the international best practice operating principles. Further, the paper presents insights on the substantive contribution of public participation in environmental risk management based on questionnaire survey responses from EIA Practitioners and other stakeholders in Kenya's renewable energy sub-sector. Results show that public participation practice during EIA in Kenya loosely adheres to the international best practice operating principles. An analysis of stakeholder responses shows that public participation during EIA processes in the renewable energy sub-sector seldom supports decisions that result in environmental protection. Factors that contribute to Kenya's poor adherence to international best practice operating principles are discussed. Suggestions and recommendations on how to achieve a substantive contribution of public participation during EIA in Kenya's renewable energy projects in order to contribute to environmental risk management are presented.

Keywords: public participation, Environmental Impact Assessment, renewable energy, Kenya.
\end{abstract}

\section{INTRODUCTION}

Environmental Impact Assessment (EIA) is one of the processes that culminate to an environmental decision [1]-[3]. Most of EIA systems worldwide have embedded within them the requirement of public participation [4]-[11]. Whilst many definitions of public participation abound [4], [12], a scholarly discourse on the subject accentuate the rudiments of public participation as; consultative process, public involvement, inclusiveness, information sharing, transparency and influencing outcome of decisions [12]-[14]. Public participation in EIA process according to André et al. [15] "is the involvement of individuals and groups that are positively, or negatively affected by, or that are interested in, a proposed project, program, plan or policy, that is subject to a decision-making process". Public participation requirement during EIA process is underpinned in an array of international legal instruments such as the Aarhus Convention, United Nation Conference on Environment and Development, Convention on Environmental Impact Assessment in a Trans-boundary 
Context, North American Agreement on Environmental Cooperation, Principle 17 of the 1992 Rio Declaration on Environment and Development and Agenda 21 [1], [2], [9], [16]. In Kenya, public participation during EIA process is a constitutional requirement [17], [18]. The Environmental Management and Coordination Act, 1999 (Amended) 2015 which gives effects to article 69 of the Kenya Constitution 2010, makes public participation during EIA mandatory [3], [17], [19]-[21]. Public participation during EIA process is vital because it informs decision making, reduces conflicts, enhances transparency and accountability, builds trust, capture local and traditional knowledge, provide adequate opportunities to stakeholders to raise their concerns, educate stakeholders, increase awareness, build trust and legitimises public decisions [22]-[24]. Whereas public participation in EIA process is viewed as a means of nurturing a new ethos of environmental responsibility [25] for sustainable development [26], scholarly discourse continues on how it should be conducted [14]. Notwithstanding its importance [22], [23] its design and implementation remain contentious [14], [23], [24]. The objectives of this study were thus twofold, first to compare public participation practice during EIA process in Kenya vis-à-vis the international best practice operating principles. Secondly to find out the perceptions of EIA practitioners and other EIA stakeholders on the substantive contribution of public participation (during EIA process) to environmental decisions and environmental risk management in Kenya's renewable energy sub-sector.

\section{METHODOLOGY}

In line with the objectives, the research methodology was twofold. First, a comparative analysis of public participation practices during EIA process for renewable energy projects in Kenya vis-à-vis the international best practice operating principles of public participation. Secondly, a questionnaire survey among EIA Practitioners and other EIA stakeholders in Kenya's renewable energy sector. The international best practice operating principles of public participation adopted are according to André, et al. [15] while the Kenya public participation practice was as in Mwenda et al. [8], Mwenda and Kibutu [17], Kibutu and Mwenda [20]. Questionnaire respondents were sampled from licenced EIA practitioners in Kenya in the years 2018 while that for other stakeholders was sampled from the National Environment Management Authority (NEMA) Environmental Officers, the Ministry of Energy and civil society. The sampling method used for EIA practitioners was simple random sampling while that of other EIA stakeholders was purposeful sampling [27]. Example of questions in the questionnaire include, how effective is public participation during EIA in environmental decision making in renewable energy sub-sector? Does involvement of stakeholders during EIA contribute to informed environmental decision making in renewable energy sub-sector? Are public consultation sessions during EIA effective in contributing to informed environmental decision making in the renewable energy sector? How effective is public participation during EIAs in the renewable energy sub-sector in influencing sound decisions that contribute to environmental protection? In your EIA practice how effective do you think is the EIA tool in substantively contributing to informed environmental decisions as a result of implementation of a proposed renewable energy project? How effective are the stages of EIA process including that of public participation in contributing to informed environmental decisions? The responses were on a five-point Likert Scale (1-5) as follows: 1) very ineffective, 2) ineffective, 3 ) slightly effective, 4) effective, and 5) very effective. 200 responses from EIA practitioners, 14 from Ministry of Energy, 15 from Civil Society and 13 from NEMA were analysed. 


\section{RESULTS}

3.1 Comparison of public participation practice during EIA process in Kenya with the international best practice operating principles

Table 1: Comparison of EIA International best practice operating principles of public participation with the EIA public participation practice in Kenya.

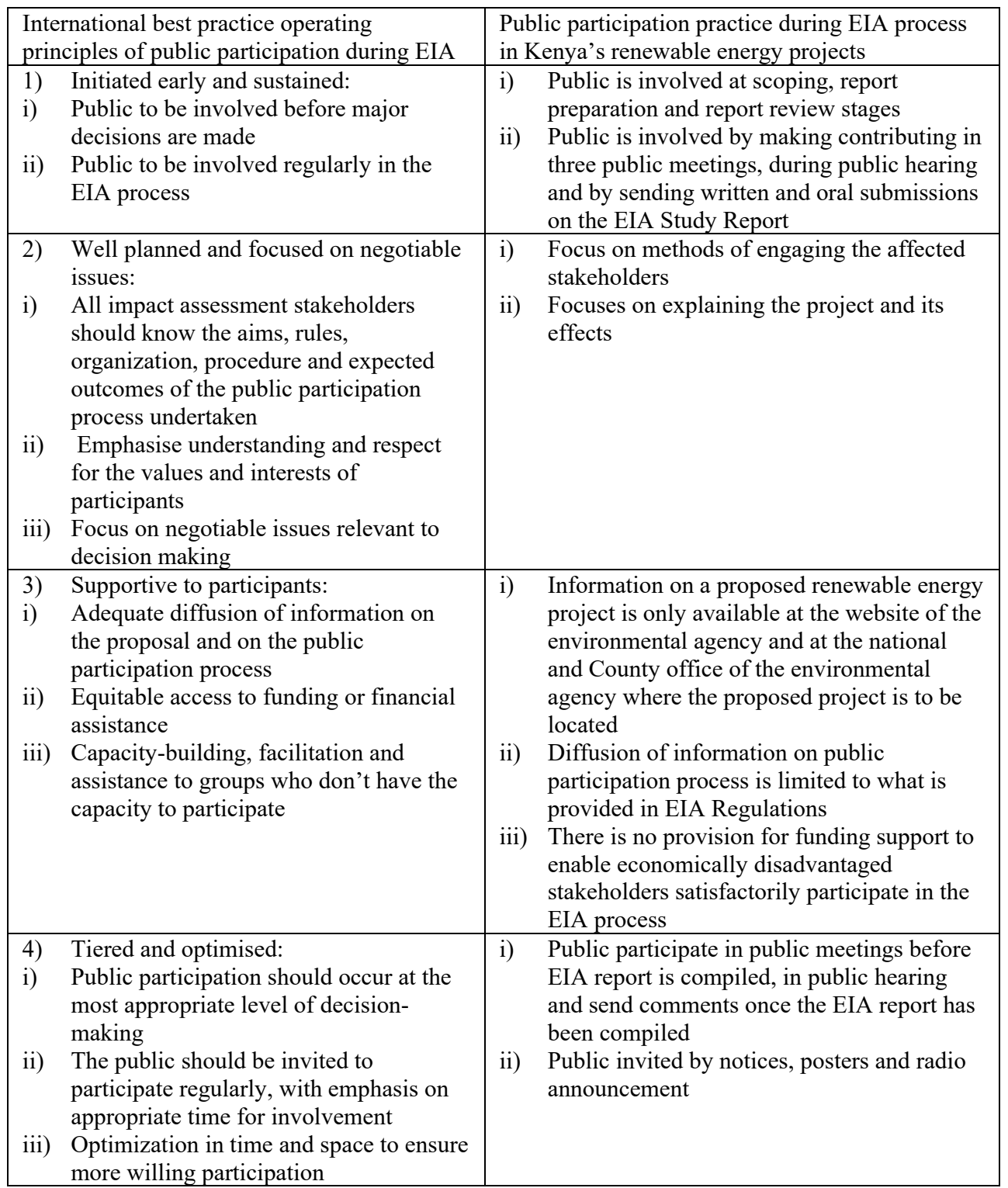


Table 1: Continued.

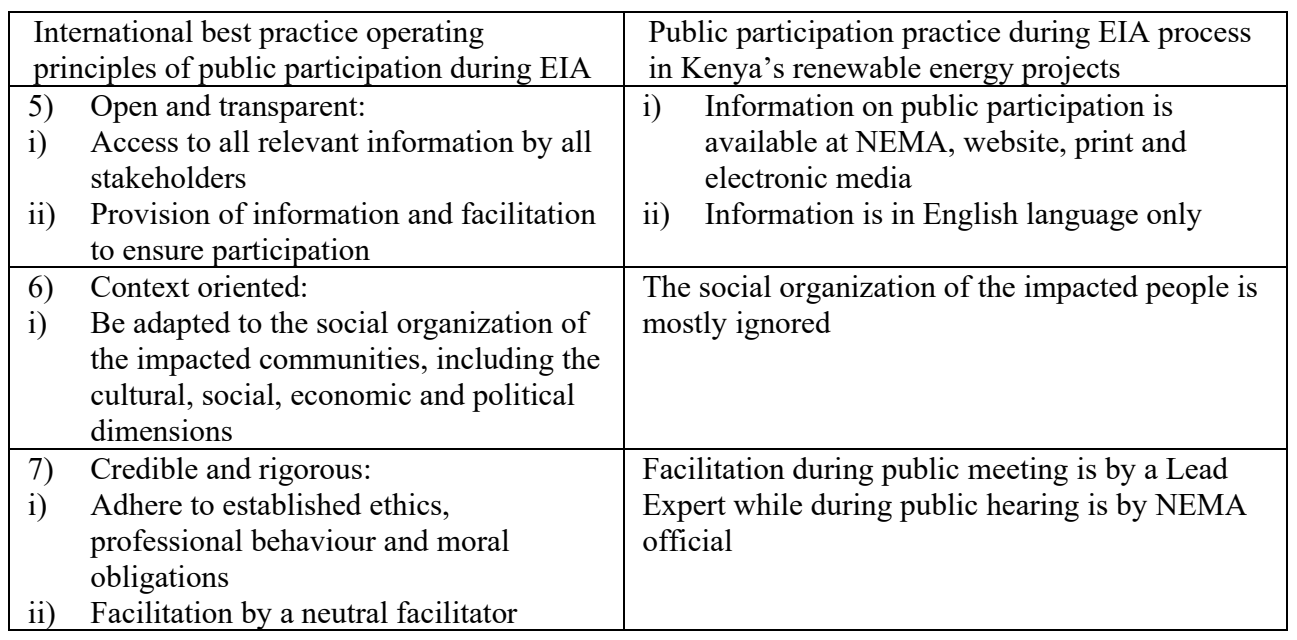

3.2 Perceptions of EIA Practitioners and other EIA stakeholders on the effectiveness of public participation' substantive contribution to environmental decisions and environmental risk management in Kenya's renewable energy sub-sector

Table 2: Statistics of the respondents on the five-point Likert scale.

\begin{tabular}{|l|c|c|c|c|c|c|}
\hline \multirow{2}{*}{$\begin{array}{l}\text { Category of } \\
\text { respondents }\end{array}$} & $\begin{array}{c}\text { Very } \\
\text { effective } \\
(1)\end{array}$ & $\begin{array}{c}\text { Effective } \\
(2)\end{array}$ & $\begin{array}{c}\text { Slightly } \\
\text { effective } \\
(3)\end{array}$ & $\begin{array}{c}\text { Ineffective } \\
(4)\end{array}$ & $\begin{array}{c}\text { Very } \\
\text { ineffective } \\
(5)\end{array}$ & $\begin{array}{c}\text { Total } \\
\text { responses } \\
(\mathrm{n})\end{array}$ \\
\hline $\begin{array}{l}\text { EIA } \\
\text { Practitioner }\end{array}$ & 12 & 29 & 29 & 95 & 35 & 200 \\
\hline $\begin{array}{l}\text { Ministry of } \\
\text { Energy }\end{array}$ & 1 & 2 & 6 & 4 & 1 & 14 \\
\hline Civil Society & 0 & 1 & 6 & 7 & 1 & 15 \\
\hline NEMA & 1 & 2 & 6 & 4 & 0 & 13 \\
\hline
\end{tabular}

\section{DISCUSSION}

4.1 Public participation practice during EIA in Kenya and its adherence to international best practice operating principles

We sort to determine how public participation practice during EIA process in Kenya's renewable energy sub-sector compares to the international best practice operating principles. Public participation during EIA process in Kenya is in three main stages namely at the scoping, storage, EIA report preparation stage and EIA report review stage. The first two stages are mainly sharing of proposed project information with the public while the third stage is mainly consultative in nature. Documented research has shown that information sharing form of public participation is passive public participation, it is viewed as non-participation, manipulative depicted by therapy as it is subsequent to decisions that have already been taken without inputs from the stakeholders [28]-[30]. Research has shown that 
public hearing is an ineffective form of public participation "it does not result in genuine participation, does not satisfy the public, seldom improve decisions as it does not include broad spectrum of the public but instead contributes to antagonising the public" [31]. The comparative analysis identified the following shortcomings of Kenya's public participation during EIA; public participation is not initiated early nor sustained throughout the EIA process because stakeholders such as community members of the proposed project site are not involved in early project stages of design, nor in the determination of project location further, stakeholders do not directly participate in the project approval stage. The practice is not well planned and does not focus on negotiable issues because it is organisationally deficient of a clear outline of what its aim is, rules and procedure to be followed and the expected outcome. It does not identify issues that stakeholders will negotiate on in order to aid decision making as stakeholders are viewed as a recipient of project information as opposed to equals capable of influencing project decision. Information diffusion on public participation and capacity building are both too limiting and prohibiting by design, location and language because capacity building for better public participation during EIA process is not actualised. Language used in notices, posters and radio announcement is commonly English which locks out many stakeholders. Information access is prohibitive as one will require access to internet and the requisite technical capacity to retrieve required information from relevant databases. The practice is not context oriented as cultural, social, economic and political dimensions are mostly ignored nor is it credible and rigorous as facilitators are interested parties and hence not neutral. Similar findings have been document in previous studies including Okello et al. [21] who concluded that public participation in Kenya's EIA process "is poor, particularly during the scoping, report review and follow-up stages" [8], who states that public participation within EIA process in Kenya is relatively low [32], who states that public participation in Kenya's EIA process is inadequate [33], who states that project "developers do not usually favour public participation, because they do not see the positive side of this process as a result, they are likely to hide information, or not clearly state data that may be controversial". Public participation in environmental decision making is both shaped by and, in many cases, constrained by the ways in which environmental issues, problems, and solutions are defined or framed through the strategic communication practices of the participants [34]. Exhaustive, inclusive and satisfactory public participation integrates local knowledge [2], broadens potential solutions [14], [35], [36], improves process outcomes [37] and avoids costly and time-consuming conflicts [38] thus guarantying access to justices in matters environment [14]. In line with the principles of informative, proactive and early involvement, the public should be involved as soon as value judgement becomes salient [13] in order to consider psychological and sociological understandings of risk [39]. These two principles underscore the importance of early public participation in the discourse of underlying assumptions and agenda setting as opposed to narrow predefined problems [40]. Effective public participation should be broad capturing representation of all affected public [13] for inclusivity, equitability, openness and transparency [17]. In order for public participation process to be considered truly imputable, the output of the participation should have a genuine impact on policy [13] otherwise the participation could be perceived as merely being used to legitimise already made decisions [28] as opposed to contributing to influencing sound environmental decision making [37]. Interactive participation is viewed as the only public participation method that enables stakeholders take control over decisions thus gaining a stake in mainstreaming structures and resources [29]. Interactive participation utilises systematic structured learning process from a multidisciplinary approach that enables stakeholders take control over decisions include resource usage. It enables stakeholders' 
participation in joint analysis, development of action plans and formation of and or strengthening of local institutions.

\subsection{Public participation during EIA process in Kenya and substantive contribution to} environmental decisions and environmental risk management

The substantive contribution of public participation during EIA process in environmental decision making and hence environmental risk management focuses on a number of issues including stakeholder participation [41]. It is on this basis we explored the perceptions of stakeholders who participate in EIA public participation process in Kenya's renewable energy sub-sector to establish how they perceive the effectiveness of their participation in substantively contributing to environmental decisions and hence environmental risk management. Results show a small percentage of between 6 and 8 (Figs 1-4) of respondents from each category perceive public participation during EIA process as being very effective in substantively contributing to environmental decisions for environmental risk management in the renewable energy sub-sector. A majority of the respondents from EIA practitioners (48\%) (Fig. 1) and civil society (46\%) (Fig. 3) and a significant percentage from NEMA (31\%) (Fig. 4) and Ministry of Energy (29\%) (Fig. 2) perceive public participation during EIA process as ineffective in substantively contributing to environmental decisions for environmental risk management in the renewable energy sub-sector. Research has shown that substantive contribution of public participation during EIA process in environmental decision making is influenced by and depended on local information and knowledge, incorporating experimental and value based knowledge and testing the robustness of information from other sources [24], [36], [42]. It could thus be argued that the observed perception of ineffectiveness of public participation's substantive contribution to environmental decisions could be attributed to inability of exhaustively harnessing local knowledge from local community stakeholders during public participation and incorporating the knowledge in environmental decisions. Research has also shown that unjust EIA procedures characterised by inequitable opportunity and freedom of affected communities to participate in the EIA process contribute to poor public participation of the affected stakeholders [43]. The outcomes of such an EIA procedure cannot support informed environmental decision but instead contribute to harming the environment [43]. Public participation is part of EIA process, poor public participation or lack of it amounts to unjust EIA procedures. Such unjust EIA procedures negate the substantive rationale of EIA which is to inform decision-making in order to mitigate negative environmental impacts [44] which will in turn contribute to environmental protection.

Whereas progress has been made in constitutionally and legislatively underpinning public participation in Kenya's EIA process, there is scanty information on actual execution. Constitutional and legislative loopholes are evident in Kenya's legal framework on public participations during EIA process. The constitution of Kenya falls short of making public participation mandatory in managing, conserving and protecting the environment but instead require the state to encourage public participation in the management, protection and conservation of the environment as captured in article 69(1)(d) [45]. To 'encourage' means to "give support, courage or hope" [46], waters down what could otherwise have been a mandatory constitutional requirement. The Environmental Management and Coordination Act, (EMCA) 1999 (Amended) 2015 and the Environmental (Impact Assessment and Audit) Regulation, 2003 provides for public participation during EIA process in Kenya [17]. These legislations fall short of defining the threshold required for public participation during EIA process to be considered imputable, credible and acceptable. Section 59 of EMCA provides 
for advertising an already prepared EIA study report in a newspaper, Kenya Gazette and radio and in the authority's website [47] as a form of public participation, this is passive participation. The EIA Regulation, 2003 which should spell out the nitty-gritties of public participation during EIA process to ensure that public participation is rigorous, exhaustive and all inclusive, instead reduces the process to "three public meetings" at strategic locations of the proposed project site [48]. The regulations only attempt to define how the public will be informed of the location and timings of the public meetings but fails to state how the process should be conducted to ensure credibility.

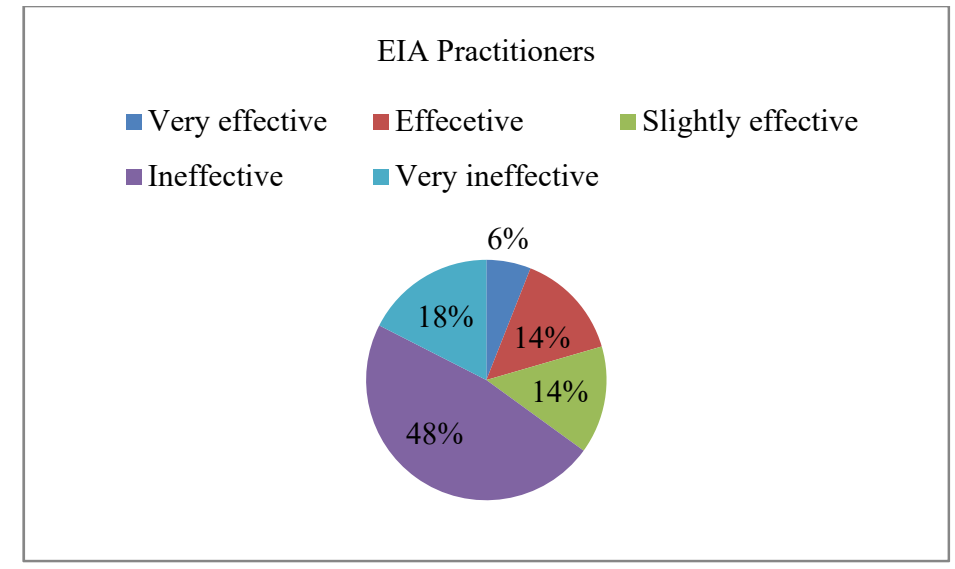

Figure 1: Perceptions of respondents of EIA practitioners on the effectiveness of public participation's substantive contribution to environmental decisions in Kenya's renewable energy sub-sector.

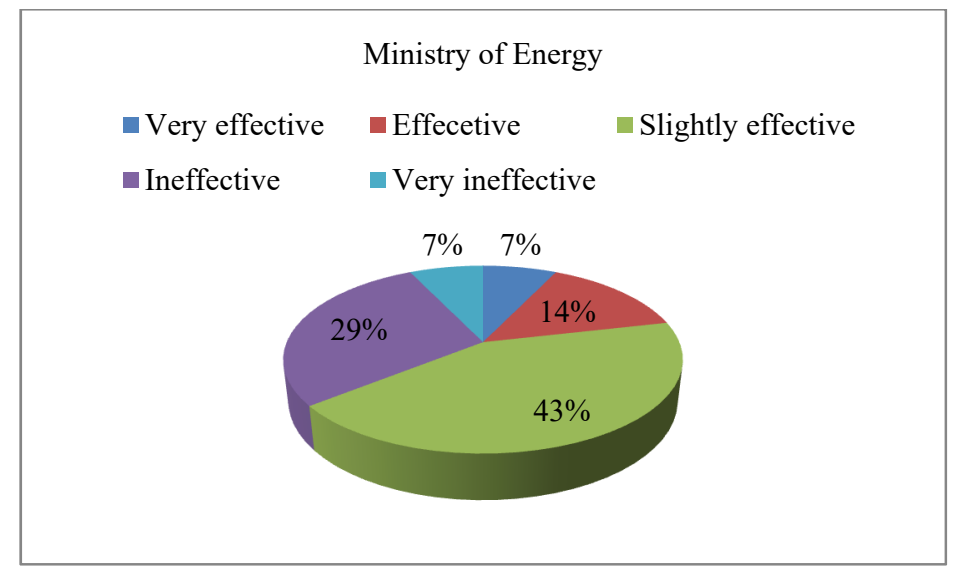

Figure 2: Perceptions of respondents from the ministry of Energy on the effectiveness of public participation's substantive contribution to environmental decisions in Kenya's renewable energy sub-sector. 


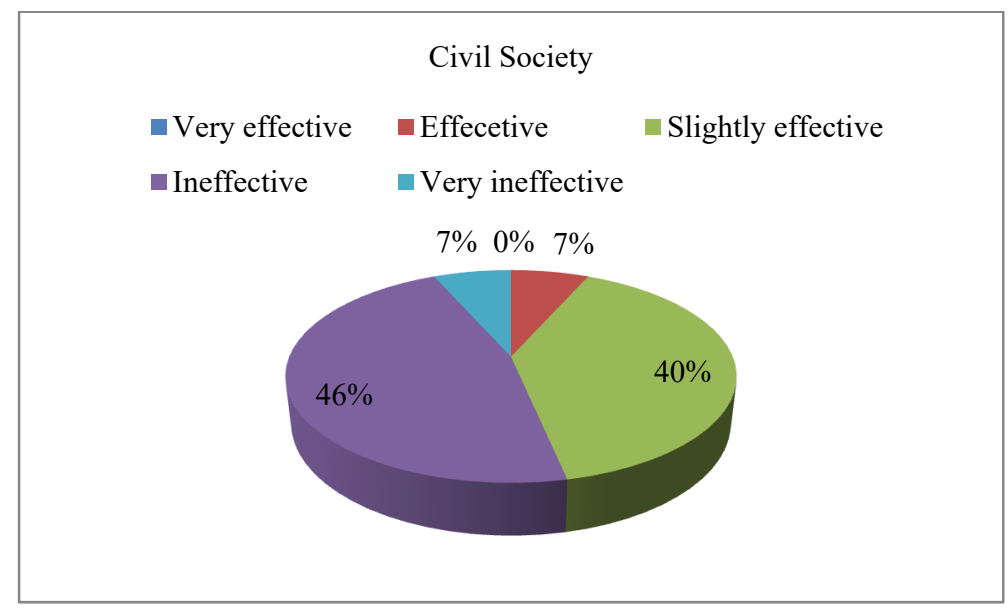

Figure 3: Perceptions of respondents from the civil society on the effectiveness of public participation's substantive contribution to environmental decisions in Kenya's renewable energy sub-sector.

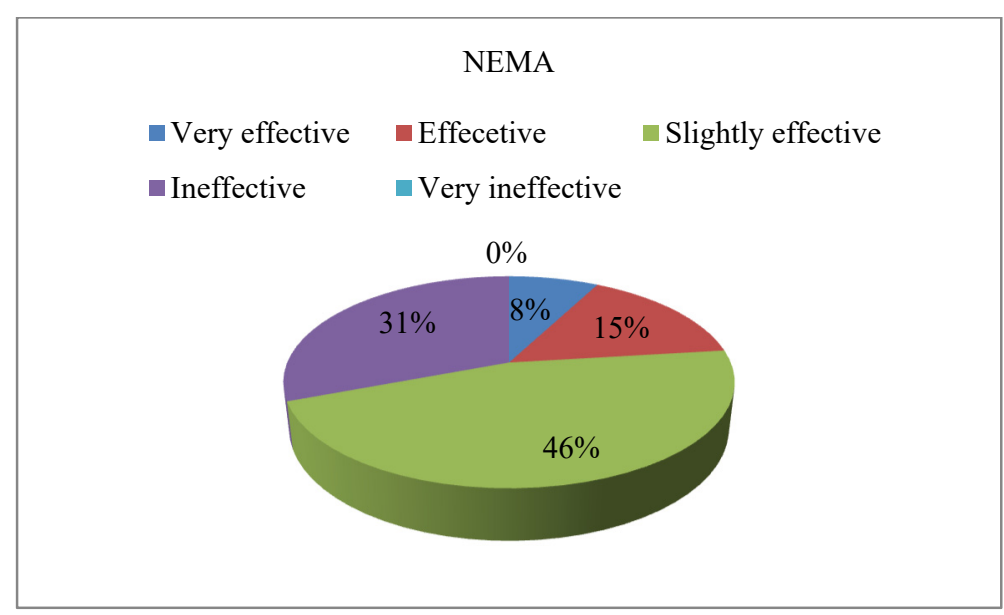

Figure 4: Perceptions of respondents from NEMA on the effectiveness of public participation's substantive contribution to environmental decisions in Kenya's renewable energy sub-sector.

\section{CONCLUSION}

Whilst the most appropriate method of public involvement depends on the specifics of any particular situation and that more knowledge-based decisions require lower levels of involvement than more value-based decisions, the forms of public participation used in the EIA process in Kenya are not satisfactorily interactive to a level where stakeholders take control over decisions thus gaining a stake in mainstreaming structures and resources. Public participation during EIA process in Kenya's renewable energy sub-sector therefore lacks the 
merits of the international best practice operating principles because it is not initiated early and is not sustained throughout the EIA process; it is not well planned and does not focus on negotiable issues; information diffusion and capacity building is too limiting and prohibiting by design, location and language; cultural, social, economic and political dimensions are mostly ignored and facilitators are interested parties most likely not neutral. The outcome of such a public participation for an EIA process seldom supports informed environmental decisions and hence cannot contribute to environmental risk management. The same finding is mirrored in the outcome of stakeholder perceptions (EIA practitioners, civil society, Ministry of Energy and NEMA respondents) where there is a general consensus that public participation during EIA process is ineffective in substantively contributing to informed decision making. This study has thus established that public participation during EIA process in Kenya's renewable energy sub-sector poorly adheres to the international best practice principles of public participation. The outcome of stakeholder perceptions on the substantive contribution of public participation in environmental decision making is that it rarely supports well informed decision-making that result in environmental protection in the renewable energy sub-sector in Kenya. The perception could be attributed to the poor adherence of the public participation practice to international best practice principles as seen in the shortcoming of the practice in Kenya. The outcomes thus show that for public participation to substantively inform decision making towards environmental protection, in order to minimise environmental risks, public participation during EIA in Kenya's renewable energy sub-sector should strictly adhere to the established international best practice operating principles.

\section{RECOMMENDATIONS}

To achieve substantive contribution of public participation during EIA in Kenya's renewable energy sub-sector, the current forms of public participation that are largely passive in nature should be substituted with interactive participation. The interactive stakeholder participation should begin from project conceptualization stage and sustained though the entire project cycle. To achieve this, it will be important for a review and broadening of the current EIA legislation in Kenya to provide for a standalone piece of legislation that is specific to public participation during environmental impact assessment process.

\section{ACKNOWLEDGEMENTS}

Special thanks to EIA practitioners, government agencies and civil society for responding to the questionnaire, Dr Jatin Nathwani, and the Global Change Initiative - Affordable Energy 4 Humanity $(\mathrm{AE} 4 \mathrm{H})$ which he spearheads at the Waterloo Institute for Sustainable Energy, University of Waterloo, Canada for the valuable advice and support.

\section{REFERENCES}

[1] Richardson, B.J. \& Razzaque, J., Public participation in environmental decisionmaking. Environmental Law for Sustainability, 6, pp. 165-194, 2006.

[2] Ocampo-Melgar, A., Sagaris, L., \& Gironás, J., Experiences of voluntary early participation in environmental impact assessments in Chilean mining. Environmental Impact Assessment Review, 74, pp. 43-53, 2019.

[3] Okello, N., Beevers, L., Douven, W. \& Leentvaar, J., The doing and un-doing of public participation during environmental impact assessments in Kenya. Impact Assessment and Project Appraisal, 27(3), pp. 217-226, 2009. 
[4] Marzuki, A., A review on public participation in environmental impact assessment in Malaysia. Theoretical and Empirical Researches in Urban Management, 4(12), pp. 126-36, 2009.

[5] Ruffeis, D., Loiskandl, W., Awulachew, S.B. \& Boelee, E., Evaluation of the environmental policy and impact assessment process in Ethiopia. Impact Assessment and Project Appraisal, 28(1), pp. 29-40, 2010.

[6] Marara, M., Okello, N., Kuhanwa, Z., Douven, W., Beevers, L. \& Leentvaar, J., The importance of context in delivering effective EIA: Case studies from East Africa. Environmental Impact Assessment Review, 31(3), pp. 286-296, 2011.

[7] Nadeem, O. \& Fischer, T.B., An evaluation framework for effective public participation in EIA in Pakistan. Environmental Impact Assessment Review, 31(1), pp. 36-47, 2011.

[8] Mwenda, A.N., Bregt, A.K., Ligtenberg, A. \& Kibutu, T.N., Trends in consultation and public participation within environmental impact assessment in Kenya. Impact Assessment and Project Appraisal, 30(2), pp. 130-135, 2012.

[9] Morgan, R.K., Environmental impact assessment: the state of the art. Impact Assessment and Project Appraisal, 30(1), pp. 5-14, 2012.

[10] Rebelo, C. \& Guerreiro, J., Comparative evaluation of the EIA systems in Kenya, Tanzania, Mozambique, South Africa, Angola, and the European Union. Journal of Environmental Protection, 8(5), pp. 603-636, 2017.

[11] Glucker, A.N., Driessen, P.P., Kolhoff, A. \& Runhaar, H.A., Public participation in environmental impact assessment: why, who and how? Environmental Impact Assessment Review, 1(43), pp. 104-111, 2013.

[12] Slocum, R. \& Thomas-Slayter, B., Participation, Empowerment and Sustainable Development. Power, Process and Participation: Tools for Change. Intermediate Technology Publications: London, pp. 3-8, 1995

[13] Rowe, G. \& Frewer, L.J., Public participation methods: A framework for evaluation. Science, Technology, \& Human Values, 25(1), pp. 3-29, 2000.

[14] Hartley, N. \& Wood, C., Public participation in environmental impact assessment: Implementing the Aarhus Convention. Environmental Impact Assessment Review, 25(4), pp. 319-340, 2005.

[15] André, P., Enserink, B., Connor, D. \& Croal, P., Public participation international best practice principles. Special Publication Series, 4, 2006

[16] Kolhoff, A.J., Driessen, P.P. \& Runhaar, H.A., Overcoming low EIA performance: A diagnostic tool for the deliberate development of EIA system capacities in low and middle income countries. Environmental Impact Assessment Review, 68, pp. 98-108, 2018.

[17] Mwenda, A. \& Kibutu, T.N., Implications of the new constitution on environmental management in Kenya. Law, Environment \& Development Journal, 8, p. 76, 2012.

[18] Kibugi, R., Development and the balancing of interests in Kenya. The Balancing of Interests in Environmental Law in Africa, p. 169, 2011.

[19] Kameri-Mbote, P., Strategic planning and implementation of public involvement in environmental decision-making as they relate to environmental impact assessment in Kenya. Nairobi, Kenya., International Environmental Law Research Center Working Paper, 2000-3, 2000.

[20] Kibutu, T.N. \& Mwenda, A.N., Provision for environmental impact assessment (EIA) in Kenya's legislation: A review of the Environmental Management and Coordination Act (EMCA) and Environmental (Impact Assessment and Audit) Regulations (EIAAR). Eastern Africa Journal of Humanities and Sciences, 10(2), pp. 1-3, 2010. 
[21] Okello, N., Douven, W., Leentvaar, J. \& Beevers, L., Breaking Kenyan barriers to public involvement in environmental impact assessment. Proceedings of the Annual Conference of the International Association for Impact Assessment, 19, pp. 1-5, 2000.

[22] Innes, J.E. \& Booher, D.E., Reframing public participation: Strategies for the 21st century. Planning Theory \& Practice, 5(4), pp. 419-436, 2004.

[23] Stewart, J.M. \& Sinclair, A.J., Meaningful public participation in environmental assessment: Perspectives from Canadian participants, proponents, and government. Journal of Environmental Assessment Policy and Management, 9(2), pp. 161-83, 2007.

[24] O'Faircheallaigh, C., Public participation and environmental impact assessment: Purposes, implications, and lessons for public policy making. Environmental Impact Assessment Review, 30(1), pp. 19-27, 2010.

[25] Engel, J.R., The faith of democratic ecological citizenship. The Hastings Center Report, 28(6), pp. 31-34, 1998.

[26] Chi, C.S., Xu, J. \& Xue, L., Public participation in environmental impact assessment for public projects: A case of non-participation. Journal of Environmental Planning and Management, 57(9), pp. 1422-1440, 2014.

[27] Kothari, C.R., Research Methodology: Methods and Techniques. New Age International, 2004.

[28] Cornwall, A., Unpacking 'participation': models, meanings and practices. Community Development Journal, 43(3), pp. 269-283, 2008.

[29] Pretty, J.N., Participatory learning for sustainable agriculture. World Development, 23(8), pp. 1247-1263, 1995.

[30] Arnstein, S.R., A ladder of citizen participation. Journal of the American Institute of Planners, 35(4), pp. 216-224, 1969.

[31] Innes, J.E. \& Booher, D.E., Reframing public participation: Strategies for the 21st century. Planning Theory \& Practice, 5(4), pp. 419-436, 2004.

[32] Kakonge, J., Environmental impact assessment: Why it fails in Kenya. Pambazuka News, 2015.

[33] Enríquez-de-Salamanca, Á., Stakeholders' manipulation of environmental impact assessment. Environmental Impact Assessment Review, 68, pp. 10-18, 2018.

[34] Depoe, S.P., Delicath, J.W. \& Elsenbeer, M.F. eds., Communication and Public Participation in Environmental Decision Making, Albany: SUNY Press, 2004.

[35] Vanclay, F., International principles for social impact assessment. Impact Assessment and Project Appraisal, 21(1), pp. 5-12, 2003.

[36] Morrison-Saunders, A. \& Early, G., What is necessary to ensure natural justice in environmental impact assessment decision-making? Impact Assessment and Project Appraisal, 26(1), pp. 29-42, 2008.

[37] Sinclair, A.J., Diduck, A. \& Fitzpatrick, P., Conceptualizing learning for sustainability through environmental assessment: Critical reflections on 15 years of research. Environmental Impact Assessment Review, 28(7), pp. 415-428, 2008.

[38] Diduck, A. \& Mitchell, B., Learning, public involvement and environmental assessment: A Canadian case study. Journal of Environmental Assessment Policy and Management, 5(3), pp. 339-364, 2003.

[39] Renn, O., Webler, T., Rakel, H., Dienel, P. \& Johnson, B., Public participation in decision making: A three-step procedure. Policy Sciences, 26(3), pp. 189-214, 1993.

[40] Moffet, J., Environmental priority setting based on comparative risk and public input. Canadian Public Administration, 39(3), pp. 362-385, 1996. 
[41] Chanchitpricha, C., Bond, A. \& Cashmore, M., Effectiveness criteria for measuring impact assessment tools. SEA Implementation and Practice: Making an Impact, 43, pp. 1-13, 2011.

[42] Abaza, H., Bisset, R. \& Sadler, B., Environmental impact assessment and strategic environmental assessment: towards an integrated approach. UNEP/Earthprint, 2004.

[43] Simpson, N.P. \& Basta, C., Sufficiently capable for effective participation in environmental impact assessment? Environmental Impact Assessment Review, 70, pp. 57-70, 2018.

[44] Loomis. J.J. \& Dziedzic, M., Evaluating EIA systems' effectiveness: a state of the art. Environmental Impact Assessment Review, 68, pp. 29-37, 2018.

[45] Constitution of Kenya, Government printer, Nairobi, 2010.

[46] Hornby, A.S., Cowie, A,P., Gimson, A.C. \& Hornby, A.S., Oxford Advanced Learner's Dictionary of Current English, Oxford: Oxford University Press, 1974.

[47] The Environmental Management and Co-ordination (Amendment) Act, 2015, Kenya Gazette Supplement No. 74, Acts No. 5, 2015.

[48] Kenya, Environmental (Impact Assessment and Audit) Regulations, Legal Notice No. 101, Kenya Gazette Supplement No. 56, Legislative Supplement No. 31, 2003. 